\title{
Malignant Neoplasms of The Head And Neck: Aspects Associated With Mortality
}

\author{
Jussara De Lucena Alves ${ }^{1}$, Mayara Cedrim Santos ${ }^{2}$, Bruna Gabrielle De Souza \\ Costa $^{3}$, Simone Yuriko Kameo ${ }^{4}$ \\ ${ }^{I}$ Nurse, Chemotherapy Ambulatory Of University Hospital Professor Alberto Antunes. Federal University Of \\ Alagoas, Maceió,Alagoas, Brazil,; \\ ${ }^{2}$ nurse, Surgical Department Of University Hospital Professor Alberto Antunes. Federal University Of Alagoas, \\ Maceió,Alagoas, Brazil, \\ ${ }^{3}$ Nurse, Chemotherapy Ambulatory Of University Hospital Professor Alberto Antunes. Federal University Of \\ Alagoas, Maceió,Alagoas, Brazil, \\ ${ }^{4}$ Nurse, Professor Of Department Of Health Education. Federal University Of Sergipe, Lagarto, Sergipe,
}

\begin{abstract}
The aim of this research was to describe some aspects of mortality from head and neck cancer patients treated at the University Hospital in the city of Maceio, Alagoas, Brazil. A cross-sectional study was conducted, describing the characteristics of the deaths from cancer of the head and neck, between 2010 and 2014, using secondary data from the Ministry of Health of Brazil. In the period of data collection, there were 370 deaths caused by head and neck cancer, mainly located in the mouth and tongue area. The highest incidence was male (69.5\%), over 50 years old (85.4\%), with no education (27.3\%), living in the capital of Alagoas (41.6\%), principal place of death the hospital (56.2\%). Given these data, it is clear that health services should be prepared for early diagnosis of the disease to mitigate damage and reduce mortality rates. One approach to diagnosis in the initial phase of the disease should be taken for health services in order to decrease the damage and improves the prognosis of the patient, thus avoiding premature mortality.
\end{abstract}

Keywords: head and neck cancer, mortality, incidence.

\section{Introduction}

The head and neck cancer (CCP) is considered one of the malignant tumors, due to its high incidence, prevalence and mortality, and the fifth most common cancer worldwide, with an overall incidence of 780,000 new cases per year [1] . Approximately $40 \%$ of the oral cavity, $15 \%$ in the pharynx, $25 \%$ in the larynx and $20 \%$ in the salivary glands and thyroid, the incidence is higher in men than in women in the ratio of 5:1, aged over 40 years [2]. Among the most common types of cancer worldwide, the CCP occupies the sixth position in relation to mortality, accounting for about $3 \%$ of all cancers [3].

The CCP manifests in several areas of the head, scalp, skin face and neck such as lips, nasal passages, sinuses, mouth, throat, larynx, pharynx, lymph nodes, salivary glands, and the thyroid gland [4] .

In Brazil, where the cancer is the second cause of death, the CCP has shown considerable growth in its prevalence. It is estimated that there are 13 million new cases annually and over 3,000 deaths resulting from it. These data are the largest in Latin America, and the diagnosis is often delayed compared to developed countries [5].

The risk factors most associated with tumors of the head and neck are the consumption of tobacco and alcohol, both together cause a synergistic effect by frequent use, control of these factors is essential in reducing the incidence of these tumors [2,4]. There is also the relationship between infections caused by HPV (Human Papilloma Virus) sexually transmitted and the occurrence of cases of oral and oropharyngeal cancer [6]. In addition, the power restriction in intake of vegetables and fruits, occupational factors such as sun exposure and chemicals such as asbestos, are associated with cancer of the head and neck [2].

Moreover, constant diagnosis CCP is carried out in advanced clinical stages of the disease, which usually generates a greater number of cases with poor prognosis and increases the rate of sequel and deformities. These factors characterize this type of cancer as a major public health issue [7].

The aim of the research was to describe some aspects of mortality from head and neck cancer in a sample of patients who were treated at the University Hospital in the city of Maceió, Alagoas, Brazil. 


\section{Materials and Method}

This is an epidemiological and descriptive study, with a scope of a group of cancer patients, in which the occurrence of death from head and neck cancer was analyzed. This cross-sectional study, using secondary data, deaths registered in the Mortality Information System (SIM) of the Ministry of Health database (DATASUS / MS) obtained from completing the Death Certificate (DO).

Alagoas is located in Brazil's Northeast region, has 102 cities, with an estimated population in 2015 of 1,013,773 habitants, with the capital city of Maceió with 932,748 habitants [8].

Data were collected by addressing the following variables: gender, age, educational level, category ICD-10, place of occurrence, area. The research presented minimal risk to the population studied, considering it was made from secondary data, which eliminates authorization by the Ethics in Research Committee. It was waived signing the consent form clarified, since the data were collected from the SIM / DATASUS / MS.

After collecting data, descriptive statistics for all variables in the sample were made using Microsoft Excel version 2010 program, the same as for tabular and graphical presentation.

\section{Results and Discussion}

370 deaths were registered from malignant neoplasms located in the head and neck in the state of Alagoas, Brazil. The incidence of deaths caused by CCP was higher among men, $69.5 \%$ as shown in Table 1 . These data corroborate other studies $[1,10,11]$ which studied patients with head and neck cancer and also found mostly men. However, the mortality rate for CCP among women is increasing alarmingly [10], which can be seen in this study in which the number of women in cases gradually increased from $17.1 \%$ in 2010 to $37.1 \%$ in 2014 . This can be attributed to female habit changes such as increased alcohol consumption and smoking.

According to age group, the largest number of deaths concentrated in over 50 years $(85.4 \%)$ described in Table 1. In accordance with the research on the epidemiology of head and neck cancer in Brazil had the concentration of cases in the age groups 50-69 years [12].

Table 1. Mortality from malignant neoplasms of the head and neck according to sex and age. Alagoas, Brazil. 2010-2014.

\begin{tabular}{|c|c|c|c|c|c|c|}
\hline \multirow{2}{*}{ Agea } & Male & & Female & & Total & \\
\cline { 2 - 7 } & $\mathbf{N}$ & $\mathbf{\%}$ & $\mathbf{N}$ & $\mathbf{\%}$ & $\mathbf{N}$ & $\mathbf{\%}$ \\
\hline 10 a 14 years & - & & 2 & 1,8 & 2 & 0,5 \\
\hline 20 a 29 years & 4 & 1,6 & 2 & 1,8 & 6 & 1,6 \\
\hline 30 a 39 years & 11 & 4,3 & 2 & 1,8 & 13 & 3,5 \\
\hline 40 a 49 years & 25 & 9,7 & 8 & 7,1 & 33 & 8,9 \\
\hline 50 a 59 years & 78 & 30,4 & 6 & 5,3 & 84 & 22,7 \\
\hline 60 a 69 years & 58 & 22,6 & 25 & 22,1 & 83 & 22,4 \\
\hline 70 a 79 years & 51 & 19,8 & 30 & 26,5 & 81 & 21,9 \\
\hline 80 years and more & 30 & 11,7 & 38 & 33,6 & 68 & 18,4 \\
\hline Total & $\mathbf{2 5 7}$ & $\mathbf{1 0 0 , 0}$ & $\mathbf{1 1 3}$ & $\mathbf{1 0 0 , 0}$ & $\mathbf{3 7 0}$ & $\mathbf{1 0 0 , 0}$ \\
\hline
\end{tabular}

Source: SIM/DATASUS/MS

Most patients showed no level of education (27.3\%), followed by who have studied 1-3 years (15.9\%) as described in Table 2. The information produced from Hospital Cancer Registry (RHC) may occasionally present weaknesses due to the incompleteness of data [13]. This was also observed in this study, resulting in the deletion of $37.8 \%$ of database records. This loss of information is considered a limiting factor studies with secondary data.

In a survey of patients with no education, the disease has been described as one of the most cause fear in society. But despite the campaigns on the mouth self-examination, it was found that there was a lack of knowledge on the subject. This is worrying given, since the most time is the delay in diagnosis is the patient, which detects the injury, but delay to seek care [14].

Table 2. Mortality from malignant neoplasms of the head and neck to schooling. Alagoas, Brazil. 2010-2014.

\begin{tabular}{|l|c|c|c|c|c|c|c|c|c|c|c|c|}
\hline \multirow{2}{*}{ Schooling } & \multicolumn{2}{|c|}{$\mathbf{2 0 1 0}$} & \multicolumn{2}{|c|}{$\mathbf{2 0 1 1}$} & \multicolumn{2}{|c|}{$\mathbf{2 0 1 2}$} & \multicolumn{2}{|c|}{$\mathbf{2 0 1 3}$} & \multicolumn{2}{|c|}{$\mathbf{2 0 1 4}$} & \multicolumn{2}{c|}{ Total } \\
\cline { 2 - 15 } & $\mathbf{N}$ & $\mathbf{\%}$ & $\mathbf{N}$ & $\mathbf{\%}$ & $\mathbf{N}$ & $\mathbf{\%}$ & $\mathbf{N}$ & $\mathbf{\%}$ & $\mathbf{N}$ & $\mathbf{\%}$ & $\mathbf{N}$ & \% \\
\hline None & 18 & 25,7 & 16 & 29,1 & 20 & 29,4 & 26 & 29,5 & 21 & 23,6 & 101 & 27,3 \\
\hline 1 a 3 years & 13 & 18,6 & 9 & 16,4 & 12 & 17,6 & 13 & 14,8 & 12 & 13,5 & 59 & 15,9 \\
\hline 4 a 7 years & 14 & 20,0 & 6 & 10,9 & 7 & 10,3 & 5 & 5,7 & 8 & 9,0 & 40 & 10,8 \\
\hline 8 a 11 years & 2 & 2,9 & 4 & 7,3 & 5 & 7,4 & 9 & 10,2 & 2 & 2,2 & 22 & 5,9 \\
\hline 12 years and more & 1 & 1,4 & 1 & 1,8 & 1 & 1,5 & 3 & 3,4 & 2 & 2,2 & 8 & 2,2 \\
\hline Unknown & 22 & 31,4 & 19 & 34,5 & 23 & 33,8 & 32 & 36,4 & 44 & 49,4 & 140 & 37,8 \\
\hline Total & $\mathbf{7 0}$ & $\mathbf{1 0 0 , 0}$ & $\mathbf{5 5}$ & $\mathbf{1 0 0 , 0}$ & $\mathbf{6 8}$ & $\mathbf{1 0 0 , 0}$ & $\mathbf{8 8}$ & $\mathbf{1 0 0 , 0}$ & $\mathbf{8 9}$ & $\mathbf{1 0 0 , 0}$ & $\mathbf{3 7 0}$ & $\mathbf{1 0 0 , 0}$ \\
\hline
\end{tabular}

Source: SIM/DATASUS/MS 
Residence locations of people who died were divided according to the metropolitan area. In Maceió, the state capital, there were $41.6 \%$ of deaths, probably because fit the largest polo medical status. The Agreste region and other regions outside the metropolitan area recorded together $24.1 \%$.

The main place where people died was the hospital (56.2\%), then the home (40.8\%). Regarding the high percentage of deaths in the household, are considered the wear physical, emotional and psychological that the terminally ill patient and family carry, so it is necessary to adopt therapeutic approaches that respect the limits of the patient facing own your situation of incurability, causing the patient and family prefer to go through this process at his residence. [15]

As for mortality data were described average of 74 deaths per year. The locations of the cancers are described in figure 1, according to the category CID-10 C00 to C14 DATASUS / MS. The highest incidence was found in the soft parts and non-specific parts (NE) of the mouth $22.4 \%$, followed by $19.5 \%$ language. Local fewer incidents of disease were Glands salivary and Gums, with a percentage of $0.8 \%$ each. Malignant neoplasm of hypopharynx did not registered any case in the years studied. These results follow the national data from the National Cancer Institute (INCA) which confirm the CID most prevalent mortality 2009-2013 (C10, C06 and C14) [9].

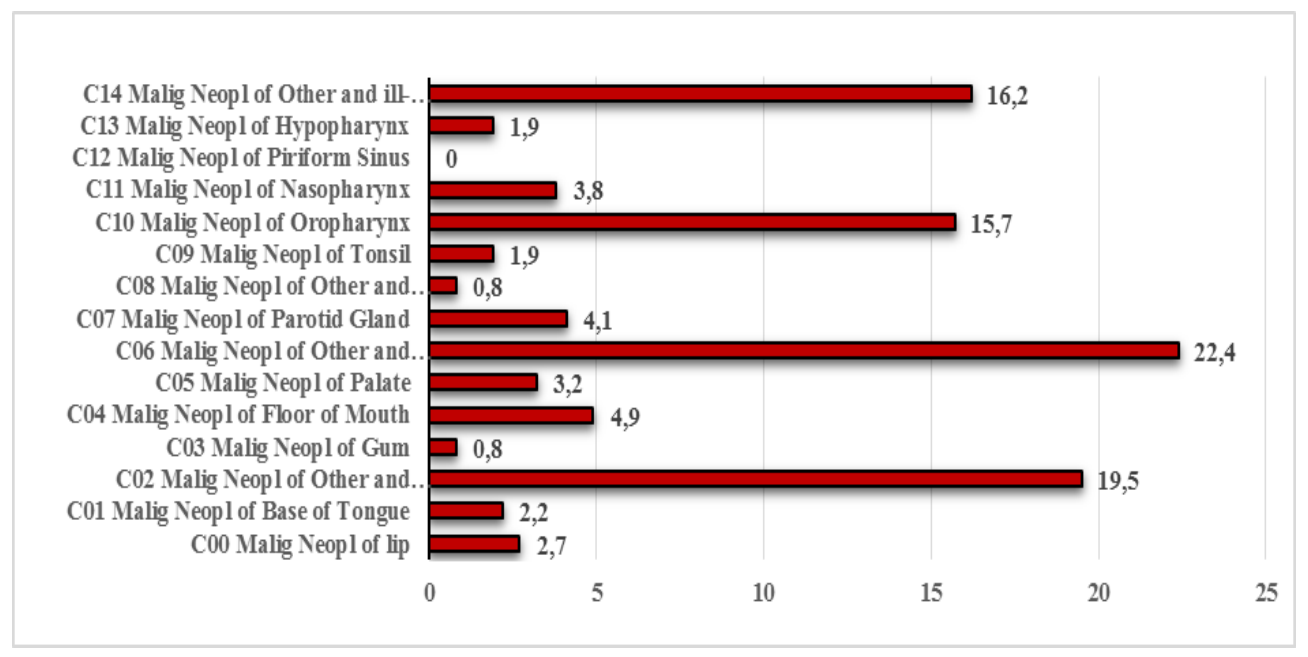

Chart 1. Mortality from malignant neoplasms of the head and neck second Category CID-10. Alagoas, Brazil, 2010-2014.

The knowledge of risk factors enhances the effective prevention of cancer [16] and, given the comorbidities and low survival rate at 5 years (30 to $40 \%)$ in the last 40 years [17].

Moreover, the results of this study aims to identify key components for decision making in prevention of lip cancer and oral cavity, guiding it is possible that a prevention directed to the factors thought to be associated is likely to contribute to reducing the incidence this cancer.

Some studies in oncology have evaluated the predisposition of individuals to cancer onset $[18,19]$, which may predispose even the recurrence of the same, before a treatment or not. In the literature, they are not well observed cases of genetic predisposition to cancer in the regions of head and neck, but cases of genetic changes acquired by the association of behavioral habits, such as smoking $[18,20]$, alcoholism $[18,20]$ viruses such as HPV [21] and even the consumption of red meat [22]. These findings suggest that prevention of this cancer becomes more feasible to combat and control factors related to the associated habits and factors amenable to intervention

\section{Conclusion}

In the years 2010-2014 there were 370 deaths caused by CCP, located mainly in the area of the mouth and tongue, mostly men, over 50 years, with low education levels. The region homes of patients who died was the state capital of Alagoas, the main place of death the hospital.

This type of cancer is concerned that involve patients who most often is still active physically and economically, bringing various disorders to life of the individual. In addition, the mortality rate has increased, the late diagnosis of cases and the risk factors that are directly related to the CCP, such as smoking.

Awareness campaigns are needed for the consumption of tobacco and alcohol, linked to therapies that help the individual to quit, aimed at preventing the CPP. In addition, education about oral hygiene from childhood is a factor that positively influences in later years, because it makes the individual has a better 
understanding of any changes that occur in the head and neck, as well as the rest of the body .

The results of this study aims to identify key components for decision-making in the prevention of head and neck cancer, guiding it is possible that a prevention directed to the factors thought to be associated is likely to contribute to reducing the incidence and mortality of this type of cancer.

One approach to diagnosis in the initial phase of the disease shall be taken for health services in order to decrease the damage and improves the prognosis of the patient, thus avoiding premature mortality.

\section{References}

[1]. Fernandes GM, Bergmann A, Oliveira JF. Análise epidemiológica de população com câncer de cabeça e pescoço: influência sobre as complicações pós operatórias. Rev. Bras. Cir. Cabeça Pescoço, v.42, no 3, p. 140-149, julho / agosto / setembro 2013.

[2]. Boing AF, Antunes JLF. Condições socioeconômicas e câncer de cabeça e pescoço: uma revisão sistemática de literatura. Ciência \& Saúde Coletiva, Florianópolis.; 2(16): 615- 22; 2011.

[3]. Aquino RCA, Lima MLPT, Menezes CRCX, Rodrigues M. Aspectos epidemiológicos da mortalidade por câncer de boca: conhecendo os riscos para possibilitar a detecção precoce das alterações na comunicação. Rev. CEFAC. 2015 Jul-Ago; 17(4):12541261

[4]. Campana IG, Goiato MC. Tumores de cabeça e pescoço: epidemiologia,fatores de risco, diagnóstico e tratamento. Revista Odontológica de Araçatuba, v.34, n.1, p. 20-26, Janeiro/Junho, 2013

[5]. BRASIL. Ministério da Saúde. Instituto Nacional do Câncer. Estimativa 2016: incidência de câncer no Brasil. Rio de Janeiro: INCA, 2016. Disponível em http://www.inca.gov.br/bvscontrolecancer/publicacoes/edicao/Estimativa_2016.pdf Acesso em: 13 jul. 2016.

[6]. Collucci C. Câncer de boca causado por sexo oral avança no Brasil. . Caderno Equilíbrio e Saúde. Folha de S.Paulo, São Paulo, 25 mai. 2011

[7]. Bergamasco VDB, Marta GN, Kowalski LP, Carvalho AL. Perfil epidemiológico do câncer de cabeça e pescoço no Estado de São Paulo. Rev Bras Cir Cabeça Pescoço;37(1):15-9, 2008

[8]. IBGE. Estatísticas populacionais. Acesso em 05/08/16. Disponível em: http://cidades.ibge.gov.br/xtras/perfil.php?codmun=270430).

[9]. BRASIL. INCA. Atlas online de mortalidade 2009-2013. Acesso em: 08/08/16. Disponível em: https://mortalidade.inca.gov.br/MortalidadeWeb/pages/Modelo02/consultar.xhtml\#panelResultado.

[10]. Antunes JLF, Toporcov TN, Biazevic MGH, Boing AF, Bastos JL. Gender and racial inequalities in trends of oral cancer mortality in Sao Paulo, Brazil. Rev Saúde Pública 2013;47(3):470-8

[11]. Alvarenga LM, Ruiz MT, Pavarino-Bertelli EC, Ruback MJC, Maniglia JV, Goloni-Bertollo EM. Avaliação epidemiológica de pacientes com câncer de cabeça e pescoço em um hospital universitário do noroeste do estado de São Paulo. Rev Bras Otorrinolaringol 2008;74(1):68-73

[12]. Casati MFM, Vasconcelos JAV, Vergnhanini GS, Contreiro PF,Graça TB, Kanda JL, el al. Epidemiologia do câncer de cabeça e pescoço no Brasil: estudo transversal de base populacional. Rev. Bras. Cir. Cabeça Pescoço, v.41, n ${ }^{4}$, p. 186-191, outubro / novembro / dezembro 2012

[13]. Souza MC, Vasconcelos AGG, Rebelo MS, Rebelo PAP, Cruz OG. Perfil dos pacientes com câncer de pulmão atendidos no Instituto Nacional do Câncer, segundo a condição tabagística, 2000 a 2007. Rev Bras Epidemiol 2014; 17 (1): 175-88.

[14]. Ferreira SMS, Santos RCN, Peixoto FB, Le Campion ACOV, Lopes FRP, Guedes TS, et al. Desenho como possível veículo de descrição das percepções e conhecimentos sobre câncer bucal de um grupo indivíduos sem formação educacional formal em Maceió, Alagoas - Brasil. Sau. \& Transf. Soc., ISSN 2178-7085, Florianópolis, v.7, n.2, p.123.-133, 2016.

[15]. BRASIL. INCA. Ações de Controle. Cuidados Paliativos. Disponível http://www2.inca.gov.br/wps/wcm/connect/acoes_programas/site/home/nobrasil/programa_controle_cancer_mama/cuidados_paliati vos. Acesso em: 08/08/16.

[16]. Oliveira LR, Silva AR, Zucoloto S. Perfil da incidência e da sobrevida de pacientes com carcinoma epidermóide oral em uma população brasileira. J Bras Patol Med Lab 2006; 42(5): 385-92.

[17]. Melo LC, Silva MC, Bernardo JMP, Marques EB, Leite ICG. Perfil epidemiológico de casos incidentes de câncer de boca e faringe. RGO 2010; 58 (3): 351-55.

[18]. Silva Jr. JA, Bernardo VG, Balassiano KZ, Soares FD, Fonseca EC, Silva LE, et al. Análise comparativa da imunoexpressão da proteína p53 (clones DO-7 e PAb-240) em carcinomas de células escamosas intrabucais e labiais. J Bras Patol Med Lab 2009; 45(4): $335-42$.

[19]. Thomas GR, Nadiminti H, Regalado J. Molecular predictors of clinical outcome in patients with head and neck squamous cell carcinoma. Int J Exp Pathol 2005; 86(6): 347-63.

[20]. Leme CVD, Raposo LS, Ruiz MT, Biselli JM, Galbiatti ALS, Maniglia JV, et al. Análise dos genes GSTM1 e GSTT1 em pacientes com câncer de cabeça e pescoço. Rev Assoc Méd Bras 2010; 56(3) 299-303.

[21]. Rotnáglová E, Tachezy R, Salákova M, Procházka B, Koslábová E, Veselá E, et al. HPV involvement in tonsillar cancer: prognostic significance and clinically relevant markers. Int J Cancer 2011; 129(1): 101-10.

[22]. Marchioni DML, Gattás GJF, Curioni OA, Carvalho MB. Interação entre consumo alimentar e polimorfismos da GSTM1 e GSTT1 no risco para o câncer de cabeça e pescoço: estudo caso-controle em São Paulo, Brasil. Cad Saúde Pública 2011; 27(2): $379-87$. 